\title{
A study of the performance of fine wine on the Swiss market
}

\author{
Philippe Masset and \\ Jean-Philippe Weisskopf*
}

Ecole hôtelière de Lausanne, HES-SO//, University of Applied Sciences Western Switzerland and Bordeaux, Wine Economics, Route de Cojonnex 18, 1000 Lausanne 25, Switzerland Email: philippe.masset@ehl.ch Email: jean-philippe.weisskopf@ehl.ch *Corresponding author

\begin{abstract}
This paper studies the price evolution and the performance of an investment in fine wine on the Swiss market over the period 2002-2012. Using a repeat-sales-regression approach we calculate different wine indices based on auction hammer prices obtained by Steinfels Weinauktionen. Our results show that different fine wines followed a similar evolution across the sample period but that the amplitude of returns strongly depended on wine regions and types. While Bordeaux and Burgundy wines performed well, wines from the Rhône valley and Italy show a poorer performance. Compared to financial assets wine has significantly outperformed stocks, but not bonds. We further find that the Swiss franc appreciation has had a significant impact on wine prices.
\end{abstract}

Keywords: fine wine; Switzerland; auction; hammer price; alternative investment; portfolio diversification; CAPM; repeat-sales regression; foreign exchange.

Reference to this paper should be made as follows: Masset, P. and Weisskopf, J-P. (2016) 'A study of the performance of fine wine on the Swiss market', Int. J. Entrepreneurship and Small Business, Vol. 29, No. 4, pp.566-582.

Biographical notes: Philippe Masset is an Assistant Professor of Finance at the Ecole hôtelière de Lausanne. He is an active member of the Bordeaux Wine Economics group. He has extensively published in peer-reviewed journals and written book chapters in the field of wine economics.

Jean-Philippe Weisskopf is an Assistant Professor of Finance at the Ecole hôtelière de Lausanne. $\mathrm{He}$ is an active member of the Bordeaux Wine Economics group. He has extensively published in peer-reviewed journals and written book chapters in the field of wine economics.

This paper is a revised and expanded version of a paper entitled 'A study of the evolution of high-end wines in Switzerland' presented at the 2013 FMA European Conference, Luxembourg, 12-14 June 2013 and the 2012 EuroCHRIE Conference, Lausanne, 25-27 October 2012. 


\section{Introduction}

Over the last two decades the financial industry has considerably evolved with, amongst others, the emergence of numerous new asset classes. Especially physical goods have been turned into alternative (investable) assets. As a consequence, investors are allocating an increasing part of their portfolio into alternative asset classes (e.g., real estate, commodities or collectibles). Among these investment vehicles, fine wine has drawn increased attention and funds. The interest for wine has further been spurred by the outstanding vintages of 2005, 2009 and 2010 in Bordeaux that attracted unprecedented attention from worldwide media. Chris Smith of the Wine Investment Fund estimates the total stock of fine wine to be worth around USD 10 billion (Rose, 2011). A substantial part of the liquidity on this market is due to auction houses. Due to the strong demand from Asia (Masset et al., 2015) and the enthusiasm around recent Bordeaux vintages, the auction market reached a total turnover of USD 408 in 2010 respectively 478 million for 2011 (Meltzer, 2012). Since 2000 the investment market has also evolved with the launch of several large wine investment funds (Masset and Weisskopf, 2015). The main reasons for this frenetic activity are the high returns and low correlation (with traditional asset classes) that wine is supposed to deliver.

Most of the evidence on the performance of fine wine thus far has taken a US or Australian investor's perspective and mainly concentrated on Bordeaux and Australian wines. This paper expands on these findings in two distinctive ways. It is the first large scale study on the performance of fine wine on a European market. We investigate the performance of fine wine over the period 2002-2012 in Switzerland and compare it to Swiss and European bond and stock markets. The difficulty of obtaining auction hammer prices has led researchers to concentrate on the USA and Australia neglecting markets that are at the very centre of wine culture and growing. Steinfels Weinauktionen Zurich publishes hammer prices of its wine auctions, which allows us to estimate a variety of indices that track the performance of different fine wines. Second, we use a sample which not only includes Bordeaux wines but which also allows us to differentiate wines depending on their reputation and region of origin. The construction of indices not only covering first growth from Bordeaux, but also iconic wines from other regions allows us to study the evolution and segmentation of different submarkets.

While a small country, Switzerland nevertheless presents interesting characteristics that make a study of its wine market worthwhile. Switzerland is one of the richest countries in the world with a nominal GDP per capita of around 80,000 USD and GDP growth of around $2 \%$ over the last 15 years. It is also characterised by an average inflation rate of $0.9 \%$ and an unemployment rate of $3.2 \%$ over the sample period. Finally, the Swiss franc has appreciated by $20 \%$ and $27 \%$ over the period $2002-2012$ respectively 2007-2012. These macroeconomic factors have had an influence on consumer and investor behaviour. According to a study by the Swiss Wine Promotion there has been an increase of $10 \%$ in the number of consumers buying mainly foreign wines. The relatively low impact of the financial and European debt crises on the Swiss economy has further allowed consumers to purchase fine wines from the best European wine regions while US and EU customers were retracting.

The Swiss wine market is important in its own right and is comparable to the ones in larger countries. On the buy-side, Switzerland ranks as the 7th most important export destination for Bordeaux wines according to the CIVB and the 8th most important for 
Burgundy wines according to the BIVB. ${ }^{1}$ The sell-side is equally well represented with several very large wine merchants ${ }^{2}$ electing their home in Switzerland and a large number of outlets selling wine. Furthermore, some of the largest wine auctions in Europe take place in Switzerland. ${ }^{3}$ At the same time, several wine experts are Swiss or elected their base in Switzerland. For example, several members of the Grand Jury Européen, Jacques Perrin and the world's best sommelier 2013, Paolo Basso, are based in Switzerland. The increase in rankings and publications on Swiss wine have further spurred the interest in all types of wine from Swiss consumers and investors.

The structure of the paper is as follows. Section 2 discusses the relevant literature. Section 3 presents the dataset and the method to estimate wine indices. Section 4 examines the evolution of different wine indices while Section 5 compares their performance to financial assets. Section 6 concludes.

\section{Wine as an investment}

The first studies on the performance of the wine market concentrate on risk and returns of fine Bordeaux wines from a US perspective over the 1970s and 1980s. The first notable study on the performance of wine examines red Bordeaux and Californian Cabernets. Assuming storage costs of USD1.4 per bottle over the period 1973 to 1977, Krasker (1979) finds wine to underperform a riskless asset on the US market. Although wine does not yield good returns, Krasker finds two potential benefits in wine investments. Early purchase reduces real risk and returns are tax-exempt. Jaeger (1981) extends Krasker's sample to encompass data from 1969 to 1977 and reduces yearly storage costs to USD 0.499 per bottle and asserts that wine on average outperforms US Treasury-bills by 16.6\%. Covering the period 1980 to 1992 for Medoc wines, Di Vittorio and Ginsburgh (1996) look at the evolution of wine prices and the characteristics driving these prices. They find that between 1981 and 1985 wine prices increased by $75 \%$, but decreased by $15 \%$ in the consequent seven years. For the period covering 1986 to 1996, Burton and Jacobsen (2001) study post-1960 red Bordeaux from a US perspective and show that it performs poorly with nominal returns of $7.9 \%$ p.a. as opposed to $13.5 \%$ for the Dow Jones and 5.8\% for T-bonds. This negative performance gets even poorer, if insurance and storage costs, liquidity issues and difficulties in obtaining the wine are considered. They, however, also argue that single bottles or investors capable of market timing can make a profit. For example, the vintage 1982 has outperformed the Dow Jones.

At the beginning of the 2000s authors started to take an interest at the risk-return profile of non-Bordeaux wines or from a non-US investor perspective. Bentzen et al. (2002) study returns on the top 11 Bordeaux wines sold at Copenhagen's Bruun Rasmunsen auctions over the period 1988 to 2002 and observe returns of $8.7 \%$ p.a. Although these returns are high, the authors highlight the fact that most of the growth comes from the pre-1996 period, after which returns turn into a negative $3.2 \%$ p.a. Looking at determinants of wine prices they do not find a relation between Danish stock prices and wine prices. The results presented so far mainly focus on Bordeaux wines, but Australian wines have also attracted some attention. Byron and Ashenfelter (1995) find the implied annual real rate of return to storing Penfold's Grange to be $3.9 \%$ p.a. over the period $1952-1980$. This reflects a nominal rate of return of around $12 \%-13 \%$. Similarly, Fogarty (2006) finds that Australian wine had a comparable risk-return profile to 
Australian equity. Although stock returns are slightly higher, these also exhibit higher volatilities over the period 1989-2000. Over the period 1990-1996 he observes that Australian wines are outperforming their Bordeaux counterparts, while displaying lower volatilities. In a further article Fogarty (2007) argues that previous studies understate wine returns. First, investors will not all invest across the board, but some will 'wine-pick' by identifying producers and vintages that they believe have the highest return potential. Second, investors look at after-tax and not pre-tax profits. In this case wine becomes interesting as on some markets returns from wine, at a non-professional level, are tax-exempt. Third, risk-return profiles should not be compared pair-wise. Investors will not look at assets separately, but as part of their overall portfolio, as proposed by portfolio theory (Markowitz, 1952). As most investors hold many different asset classes only studying the benefits of adding wine to a portfolio and its impact on portfolio risk and return are interesting.

Authors have also started to look at wines in a more global investment context. As opposed to the studies described beforehand the following articles not only analyse the risk-return profile of fine wine but also the impact of its inclusion into a financial portfolio. Weil (1993) examines the portfolio of a single US investor over the 1970s to 1990s. This particular investor averaged a return of $9.9 \%$ p.a. His highest returns (11\%) and lowest risk (3.7\%) came from Bordeaux wines. Sanning et al. (2008) analyse the risk-return relation of Bordeaux wine with US equity in more detail. They observe that investment grade wines outperform stocks and note that fine wine displays low exposure to market risk factors, which is beneficial in terms of portfolio diversification. Using both the CAPM and (Fama-French) three-factor model they find a 7.5\%-9.5\% excess return of wine (alpha), while exposure to market risk (beta) is not significantly different from zero. Masset and Henderson (2010) extend the scope of previous papers by enlarging the sample period (1996-2007) and observe that average returns and volatility are attractive but not uniform for Bordeaux wines. Looking at portfolio theory their evidence suggests that Bordeaux wines are relatively uncorrelated with US equities. These results are also robust when higher moments (skewness and kurtosis) are contemplated. The inclusion of wine significantly increases portfolio skewness, while kurtosis is diminished. Similarly, Fogarty (2010) studies diversification benefits of Australian wines. He shows poor riskreturn characteristics of wine but its low correlation with other asset classes makes it an interesting investment from a portfolio perspective. Kourtis et al. (2012) look at investment-grade wines from different world regions and confirm Fogarty's results. Masset and Weisskopf (2010) show evidence that over the period 1996-2009 an index including French, Italian and US wine generates higher returns and a lower volatility than the US stock market. Wine also seems to lead to positive alphas and lower betas in a classic CAPM framework. Focusing on the economic crisis of 2001-2003 and the financial crisis of 2007-2009 results become even more pronounced. In a final step, Masset and Weisskopf analyse the performance of financial portfolios. The inclusion of wine increases returns, reduces risk and improves skewness and kurtosis of a financial portfolio. Recently, Fogarty and Sadler (2014) caution investors on the true ability of wine to enhance portfolio diversification. They argue that the measurement of diversification benefits may be spurious depending on the method used to construct wine indices and to measure diversification.

Based on the Swiss context and past evidence on other markets described in this section we want to test whether investors on the Swiss wine market face similar outcomes 
as those on the US or Australian markets. We thus derive two hypotheses that intend to analyse the Swiss wine market along the lines of prior evidence.

H1 Fine wine performance on the Swiss market varies according to the region of origin and reputation of wines.

H2 Fine wine outperforms financial assets such as stocks and bonds on the Swiss market.

\section{Data}

Data for this study is provided by Steinfels Weinauktionen Zurich. ${ }^{4}$ The dataset covers the period March 2002 to September 2012, with around 47,500 observations over 49 auctions and a total turnover of more than CHF 31 million. The financial data is meant to represent classic financial assets and cover stocks and bonds in which Swiss investors would invest when constituting their portfolio. It includes data on the Swiss Market Index (SMI) which is a widely used proxy for the overall stock market performance in Switzerland. The SMI comprises the 20 largest companies on the Swiss market representing around $80 \%$ of the total market capitalisation of Swiss listed companies and of the daily volume on the SIX Swiss Exchange. Similar data is obtained for the European Union as Swiss investors will seek an exposure to these markets. The Eurostoxx50 represents a pan-European basket of blue-chip stocks representing different industries and is considered a benchmark for European stock market performance. Finally, the iBoxx Euro Corporate Bonds is used as a proxy for the pan-European corporate bond market. All financial data is taken from Thomson Reuters Datastream. The 11 years covered by the dataset has the particularity of including a strong bull market (2003-2007) and three tormented financial periods (2001-2003, 2007-2009 and 2011).

\subsection{Data preparation}

The first step is to control the dataset for errors and inconsistencies in spelling. Examples of such errors are wrong bottle size classification, typos in the hammer price or in the number of bottles sold or spelling mistakes. As often as possible, errors are corrected rather than discarded, in order to keep the maximum amount of information. Second, Steinfels Weinauktionen often includes packages made of different wines in their auctions, which have to be removed due to a lack of individual information, specifically on pricing. Similarly, items such as fine spirits, wineglasses or other accessories are excluded from the calculations.

The purpose of this paper being to compare wine investments to traditional financial assets, wines used to construct the index must show a minimal market depth and liquidity. For this reason, we only keep post-1974 vintages and wines that can be considered investment grade (281 wine producers and 1,237 individual wine cuvees). ${ }^{5}$ About $10 \%$ of the wines in the original dataset are from vintages anterior to 1975, but most of them are fairly illiquid. Thus, removing them does not have a significant impact on the estimated indices. Moreover, excluding pre-1975 vintages limits potential problems due to a quality bias (e.g., label and level), which are difficult to control for. Furthermore, we only use common bottle sizes ranging from half bottles to double 
magnums. After the implementation of these filters, the dataset contains 24,651 entries ( $52 \%$ of the original dataset), representing a value of over CHF 25 million (78\%).

Our final dataset is mainly populated by red wines, with a representation of close to $93 \%$. White wines make $4 \%$ of the proposed lots, while sweet and sparkling wines account for about $1.5 \%$ each. French wines represent $89 \%$ of transactions, followed by Italy (6\%), the USA (2\%) and Spain (1\%). The remaining 2\% are from Australia, Chile and Switzerland. Within France, Bordeaux and Burgundy are most represented, with more than $90 \%$ of all trades.

The vintage distribution shows that most auctioned wines originate from the $1990 \mathrm{~s}$ (about $44 \%$ of all trades) and the 1980 s (30\%). Wines from outstanding vintages (e.g., 1982 and 1990) tend to appear more often than wines from lesser vintages (e.g., 1987 or 1991). Slightly less than $50 \%$ of the wines have been traded at a price of CHF 100 or less per bottle. Wines between CHF 100 and CHF 200 represent about $23 \%$ of the dataset and wines above CHF 500 per bottle account for $8 \%$ of the dataset. Bordeaux producers remain the most popular and traded with Mouton-Rothschild and Lafite-Rothschild accounting for respectively $20 \%$ and $10 \%$ of total sales volume. Margaux, Latour, Pétrus and Haut-Brion follow and together account for about $15 \%$ of total trading volume.

\subsection{Index construction}

In the present paper, we use repeat-sales regressions (RSR $)^{6}$ as opposed to a classic composite index used for most stock indices. This allows us to deal with two key specificities of the wine market:

1 the heterogeneity of the 'assets' traded

2 the overall lack of liquidity of the wine market.

In that we follow other wine researchers who have applied this methodology to assess the profitability of wine investments (see Burton and Jacobsen, 2001; Masset and Weisskopf, 2010). ${ }^{7}$

The RSR approach is based on repeated transactions of the same wine. The idea underlying this methodology assumes that an observed return is due to the evolution of a reference wine index plus an unexpected innovation term:

$$
\mathrm{r}_{i\left(t_{1}, t_{2}\right)}=\mathrm{r}_{I\left(t_{1}, t_{2}\right)}+\varepsilon_{i\left(t_{1}, t_{2}\right)}
$$

where $\mathrm{r}_{i\left(t_{1}, t_{2}\right)}$ corresponds to the return of wine $i$ between auctions $t_{1}$ and $t_{2}$ and $\mathrm{r}_{I\left(t_{1}, t_{2}\right)}$ is the return of the reference index over the same period of time; $\varepsilon_{i\left(t_{1}, t_{2}\right)}$ is an innovation term.

Using continuous returns, one can further rewrite the returns on both wine $i$ and index $I$ from expression (1) as:

$$
\begin{aligned}
& \mathrm{r}_{i\left(t_{1}, t_{2}\right)}=\log \left(\mathrm{P}_{i\left(t_{2}\right)}\right)-\log \left(\mathrm{P}_{i\left(t_{1}\right)}\right) \\
& \mathrm{r}_{I\left(t_{1}, t_{2}\right)}=\log \left(\mathrm{P}_{I\left(t_{2}\right)}\right)-\log \left(\mathrm{P}_{I\left(t_{1}\right)}\right)
\end{aligned}
$$

Merging equations (1) with (2a) to (2b) leads to the following expression for the return of wine $i$ in the period between auctions $t_{1}$ and $t_{2}$ : 


$$
\mathrm{r}_{i\left(t_{1}, t_{2}\right)}=\log \left(\mathrm{P}_{I\left(t_{2}\right)}\right)-\log \left(\mathrm{P}_{I\left(t_{1}\right)}\right)+\varepsilon_{i\left(t_{1}, t_{2}\right)} .
$$

In (3), two unknowns, $\mathrm{P}_{I\left(t_{1}\right)}$ and $\mathrm{P}_{I\left(t_{2}\right)}$ appear. For ease of presentation, let's replace them with $\mathrm{P}_{I\left(t_{1}\right)}=\theta_{t_{1}}$ and $\mathrm{P}_{I\left(t_{2}\right)}=\theta_{t_{2}}$. The goal of the RSR procedure is to estimate the $\theta_{t}$ coefficients for $t=1, \ldots, T$; with $t=1$ and $t=T$ corresponding to the first and last auction dates. We arrive at the following expression for $r_{i\left(t_{1}, t_{2}\right)}$,

$$
\mathrm{r}_{i\left(t_{1}, t_{2}\right)}=\mathrm{D}_{t_{1}} \theta_{t_{1}}+\mathrm{D}_{t_{2}} \theta_{t_{2}}+\varepsilon_{i\left(t_{1}, t_{2}\right)}
$$

where $D_{t_{1}}$ and $D_{t_{2}}$ are dummy variables that take values $D_{t_{1}}=-1$ and $D_{t_{2}}=1$ respectively. So far, we have only considered one return on one specific wine. Let's consider a generalised version of (4) that takes into account the returns calculated from all the repeat sales recorded within our sample,

$$
\mathrm{r}_{i\left(t_{1}, t_{2}\right)}=\sum_{t=1}^{T} \mathrm{D}_{t} \theta_{t}+\varepsilon_{i\left(t_{1}, t_{2}\right)}
$$

with,

$$
\mathrm{D}_{t}=\left\{\begin{array}{l}
-1 \text { if } t=t_{1} \\
1 \text { if } t=t_{2} \\
0 \text { otherwise }
\end{array}\right.
$$

Advocates of the RSR approach put forward that, as opposed to a hedonic approach, it controls for all wine attributes since it is based on the price appreciation of the same wine. It also requires much less data collection than a hedonic or hybrid approach as only information on prices and sales dates is needed. However, the RSR approach is built on the premise that wine characteristics do not vary through time. This can pose a problem as wine quality may not be constant. Moreover, it is not efficient on data use as only wines that are sold more than once will appear in the dataset. If there is a systematic difference between price changes in wines that have sold only once and those which have been sold more than once, then the RSR approach may provide biased estimates of overall wine price movements. Similarly, wines with a high turnover may be over-represented in the sample, possibly resulting in another bias. Finally, revisions are an issue that can affect both the RSR and hedonic approach, as re-estimation of the model may result in coefficient changes.

\section{Evolution of various wine indices}

In a first step, we construct an index representing all wines from the dataset and several sub-indices for different wine-growing regions. We thus obtain in the left panel of Figure 1 the evolution of all wines and of Bordeaux wines. The right panel shows results for wines from Burgundy, the Rhône Valley and Italy. The Bordeaux index is highly correlated (0.98) with the general wine index, as the vast majority of transactions emanate from Bordeaux. Following a sharp decline in $2002 / 2003$, wine prices have reached a peak in 2007. This has been followed by another decline with the outbreak of the financial crisis, but has experienced a fast rebound from the end of 2008 onwards. 
Since 2011 we find another decrease in prices due to the European debt crisis that has also affected the Swiss economy.

Figure 1 Evolution of different wine regions (see online version for colours)
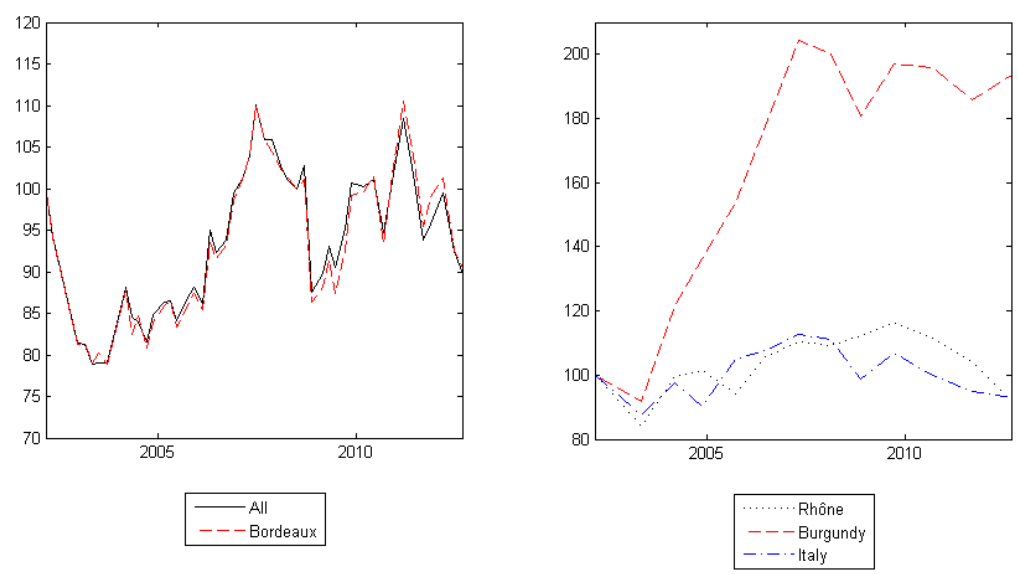

Overall, results on Italy and the Rhône Valley are similar to Bordeaux as all three yielded a similarly negative return over the period 2002-2012. They also traded in a similar band with the three indices oscillating between 80 and 110. However, the evolution diverges for Rhône Valley wines for the 2005-2010 sub-period. They take off in 2005 and do not really follow the 2007/2008 decline in Bordeaux. Only Burgundy has fared differently with the index doubling during the 2004-2006 period and staying at this level over the remainder of the period. Burgundy does seem to be the best investment on the Swiss market over the period considered.

Figure 2 looks in more detail at specific wines. The left panel looks at the most prestigious wines. These consist of two Bordeaux sub-indices and a cross-regional index. The first index looks at the five first growth wines from the Médoc. These consist of Lafite Rothschild, Mouton Rothschild, Latour, Haut Brion and Margaux to which we add La Mission Haut-Brion. A second index depicts the evolution of the most prestigious wines form the Libournais. These include all wines classified first growth A from St. Emilion (Ausone, Cheval Blanc, Angelus and Pavie) and the best wines from Pomerol (Lafleur, Le Pin and Pétrus). The myths index includes 25 wines from regions outside Bordeaux that are widely viewed as the best existing. These include, for example, the most prestigious cuvees of Gaja or Sassicaia in Italy, DRC or Roumier in Burgundy, Jaboulet's Hermitage La Chapelle in the Rhône Valley or Harlan Estate in California.

The right panel shows results for two indices representing super second wines and other investment grade wines from Bordeaux. Super-seconds are wines that are widely considered achieving quality levels close to first growths. Those wines are not necessarily classified as second growth, but it is rather their pricing that reflects their standing: they stand just in between the first growths and other classified growths. Examples of super-seconds wines include Cos d'Estournel, Pichon Comtesse, Pichon Baron, Montrose, Palmer, Ducru-Beaucaillou or Léoville Las Cases. The 'other investment grade' wines are 22 wines that are sought-after but are neither included in first growth, nor super-second wines. These consist of, amongst others, Lynch Bages, 
Léoville Poyferré, Vieux Chateau Certan, la Conseillante, Eglise Clinet, Trotanoy or Beauséjour-Duffau).

Figure 2 Evolution of Bordeaux and iconic wines (see online version for colours)
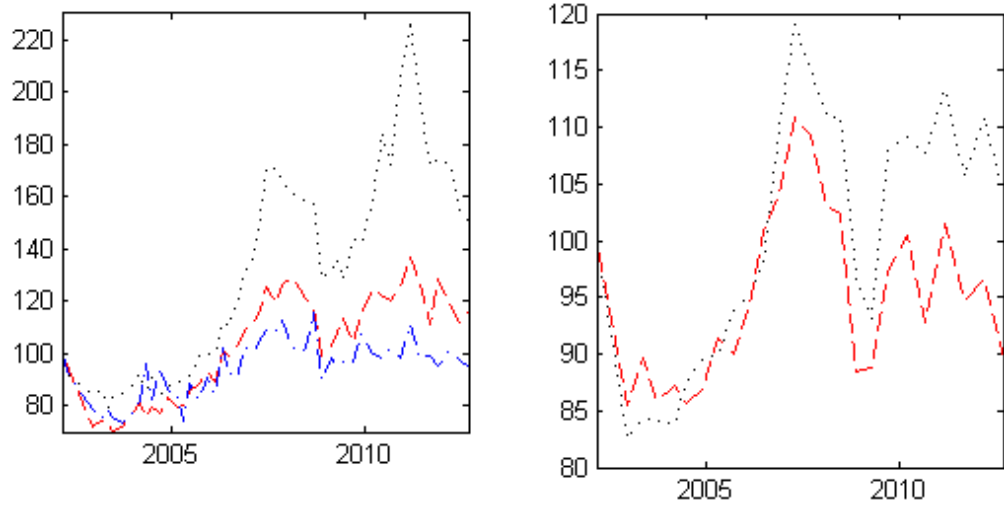

$$
\begin{aligned}
& \ldots \cdots \cdots 1 \text { st Growths (Médoc) } \\
& ---1 \text { st Growths (Libourne) } \\
& -\cdot-\cdot-\text { Myths }
\end{aligned}
$$

Figure 3 Evolution of Bordeaux first growth and equivalent wines (see online version for colours)
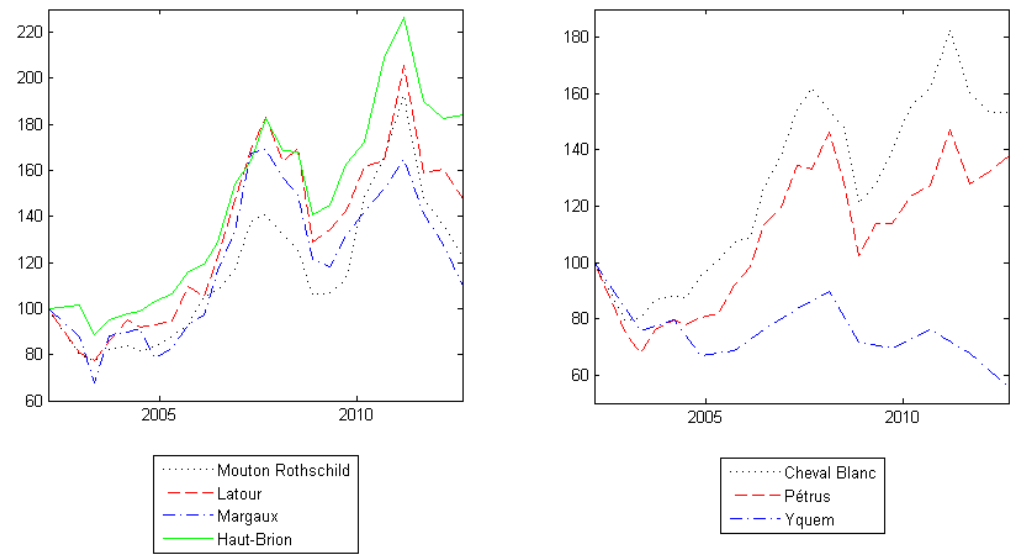

As can be noticed the first growth from the Médoc closely follow the evolution of the general (correlation of 0.81 ) and Bordeaux index (0.85). This is not surprising as it consists of the most traded wines (Lafite and Mouton Rothschild) that also impact the Bordeaux and general index. However, the amplitude is more extreme. Bordeaux wines in general went up by a maximum of $10 \%$ but the first growth of the Médoc more than doubled in price over the period 2002-2012. The first growth from the Libournais and the myths wines follow a similar evolution, but do not exhibit as high an increase as the Médoc wines. Looking at the right panel results seem to be in line with the myths and left bank first growth wines. The only notable difference comes from the amplitude of returns for the first growth of the right bank that increased much more than all other wines in the 
region or iconic wines from other regions. In the following we will be looking in more detail at the evolution of the Bordeaux first growth wines and equivalent, as these constitute the major part of transactions at wine auctions in general and at Steinfels in particular.

Figure 3 looks at the first growth from the Médoc (excluding Lafite Rothschild) in the left panel. The case of Lafite is quite particular and will be discussed in more detail in Figure 4. The right panel shows the evolution of Cheval Blanc, Petrus and Yquem.

Once again the left bank outperforms the right bank. The evolution is similar, but the amplitude of returns is different. Haut-Brion has been the best performer over the whole period, while Margaux and Mouton Rothschild have been lagging. On the left bank, it is especially Yquem that displays a poor performance. Its price has been declining steadily since 2002 losing about $40 \%-45 \%$ in ten years.

In the last few years the different wines from Lafite Rothschild have been highly demanded by Asian clients and thus are said to have performed particularly well. However, recently prices for these wines have dropped quite considerably. In Figure 4, we study this general observation. We compare an index consisting of the first growth of Médoc (excluding Lafite Rothschild) with an index solely composed by Lafite Rothschild and an index consisting of all second wines of the 6 most prestigious estates of the left bank and 4 of the right bank. It must be noted that the index on second wines is heavily relying on the Carruades de Lafite that accounts for approximately $40 \%$ of all transactions in this index.

Figure 4 Evolution of Lafite Rothschild wines (see online version for colours)

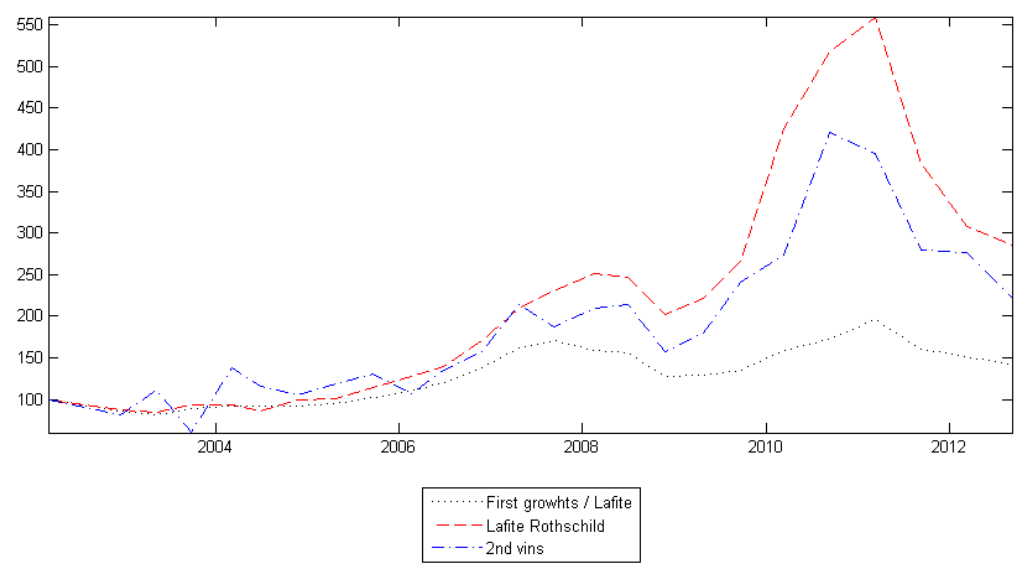

Figure 4 shows that prices for first growths wines from Médoc have risen steadily over the period. Prices for Lafite Rothschild and its second wine, Carruades de Lafite, however, increased considerably until mid-2011. Both clearly outperform all other wines with an increase of about $450 \%$ and $300 \%$ respectively over the ten year period. This price increase coincides with a growing interest from Asian customers and the emergence of a true frenzy around this estate. Since 2011, European and American customers have dropped out of this race for Lafite wines. Asian customers who were driving demand and prices have started to turn to wines from other estates in Bordeaux and Burgundy. The new anti-corruption measures installed by the Chinese Government have further added to 
this downward pressure. These results are in line with findings on the Chinese market as analysed in Masset et al. (2015).

The results for the different regions are also similar to previous findings on the US market by Masset and Weisskopf (2010). On both markets Bordeaux wines, and here especially the most reputable ones, are exchanged the most at auctions. Moreover, wines fared differently across the period 2002-2012 depending on region and reputation which lends support to Hypothesis 1. Though the general evolution is fairly similar the amplitude varies considerably. It is the most prestigious wines and especially those from the left bank in Bordeaux that performed the best. This shows that engaging in wine-picking can lead to a superior performance as compared to investing across the board.

\section{Performance analysis}

Investors rarely invest in only one asset, but normally diversify their funds into different asset classes. We not only study returns, but also the risk embedded in each index. We then devote a particular attention to both the risk-return trade-off and risk-adjusted returns of each index. The objective is to provide a general assessment of the performance of the wine market during the period under review. In this section we compare different wine indices with the evolution of stock and bond markets in Europe in general and in Switzerland in specific. The reason for analysing European markets and not only the Swiss market is twofold. First, Switzerland has strong economic and financial bands with its European neighbours which lead many Swiss investors to invest in the European Union. ${ }^{8}$ Second, the Swiss Franc has experienced an appreciation with regard to the Euro since 2008. This 30\% appreciation has had a strong impact on investment decisions. It will become more interesting for Swiss investors to buy fine wine in the Eurozone. Moreover, adjusted prices by importers for young vintages and en primeur wines will put a certain downside pressure on all wine prices, including those at auctions.

In the following, we will examine different risk and performance measures on several wine indices and financial assets including stocks and bonds from Switzerland and the Eurozone. Table 1 looks at the general wine index and four sub-indices. These include indices for the Médoc, the Libournais, the Bordeaux super seconds and one for other investment grade wines. Panel A looks at the complete period under review (2002-2012), while panel B studies the period covering the financial and economic crisis (2008-2012).

As can be noticed neither wine, nor stocks have performed well over the period 2002-2012 yielding close to zero or slightly negative returns. Returns emanating from wine further vary and do not show a consistent pattern. While first growth outperform stocks neither super seconds, nor other investment-grade wines, nor the general wine index are able to perform better than the stock market. This is further confirmed by alphas that are not significantly different from zero. Sharpe and Treynor ratios follow returns with only the first growth being positive over the period 2002-2012. However, examining other measures of risk and performance yields better results for wine. All wine indices display less risk and have a lower maximum drawdown than stocks. This is true for the complete period and the crisis period, but less so for the second. 
Table 1 Performance indicators of wine and stocks in Switzerland

\begin{tabular}{|c|c|c|c|c|c|c|}
\hline \multicolumn{7}{|c|}{ Panel A: performance of wine and stocks in Switzerland (2002-2012) } \\
\hline & All & $\begin{array}{l}\text { 1st growth } \\
\text { Médoc }\end{array}$ & $\begin{array}{l}\text { 1st growth } \\
\text { Libourne }\end{array}$ & $\begin{array}{c}\text { Super } \\
\text { second }\end{array}$ & $\begin{array}{l}\text { Other IG } \\
\text { wines }\end{array}$ & $S M I$ \\
\hline Average & $-0.9 \%$ & $3.3 \%$ & $1.3 \%$ & $-0.1 \%$ & $-1.0 \%$ & $0.2 \%$ \\
\hline Volatility & $10.4 \%$ & $15.8 \%$ & $15.2 \%$ & $15.4 \%$ & $13.3 \%$ & $19.6 \%$ \\
\hline Skewness & -0.84 & -0.31 & -1.11 & 0.14 & -0.34 & -1.47 \\
\hline Kurtosis & 4.14 & 3.02 & 5.18 & 2.15 & 2.91 & 5.99 \\
\hline Correlation & 0.60 & 0.44 & 0.47 & 0.41 & 0.46 & 1.00 \\
\hline Max. drawdown & $-21.1 \%$ & $-34.4 \%$ & $-29.4 \%$ & $-29.5 \%$ & $-23.6 \%$ & $-50.3 \%$ \\
\hline Beta & $0.32 * * *$ & $0.35 * * *$ & $0.36^{* * *}$ & $0.32 * * *$ & $0.31 * * *$ & 1.00 \\
\hline Sharpe ratio & -0.19 & 0.14 & 0.02 & -0.07 & -0.15 & -0.04 \\
\hline Treynor ratio & -0.06 & 0.06 & 0.01 & -0.03 & -0.07 & -0.01 \\
\hline Jensen's alpha & $-1.7 \%$ & $2.6 \%$ & $0.5 \%$ & $-0.9 \%$ & $-1.8 \%$ & $0.0 \%$ \\
\hline \multicolumn{7}{|c|}{ Panel B: performance of wine and stocks in Switzerland (2008-2012) } \\
\hline & All & $\begin{array}{l}\text { 1st growth } \\
\text { Médoc }\end{array}$ & $\begin{array}{l}\text { 1st growth } \\
\text { Libourne }\end{array}$ & $\begin{array}{c}\text { Super } \\
\text { second }\end{array}$ & $\begin{array}{l}\text { Other IG } \\
\text { wines }\end{array}$ & $S M I$ \\
\hline Average & $-2.4 \%$ & $-1.3 \%$ & $-0.8 \%$ & $-1.1 \%$ & $-2.7 \%$ & $-1.1 \%$ \\
\hline Volatility & $12.5 \%$ & $21.2 \%$ & $17.2 \%$ & $16.1 \%$ & $14.3 \%$ & $22.5 \%$ \\
\hline Skewness & -0.82 & -0.06 & -0.29 & 0.39 & -0.26 & -1.34 \\
\hline Kurtosis & 3.00 & 2.20 & 2.29 & 2.14 & 3.01 & 5.54 \\
\hline Correlation & 0.64 & 0.50 & 0.41 & 0.42 & 0.58 & 1.00 \\
\hline Max. drawdown & $-17.2 \%$ & $-34.4 \%$ & $-18.8 \%$ & $-19.6 \%$ & $-17.2 \%$ & $-35.0 \%$ \\
\hline Beta & $0.36^{* * *}$ & $0.47 * *$ & $0.32 *$ & $0.30^{*}$ & $0.37^{* * *}$ & 1.00 \\
\hline Sharpe ratio & -0.23 & -0.08 & -0.07 & -0.10 & -0.22 & -0.07 \\
\hline Treynor ratio & -0.08 & -0.04 & -0.04 & -0.05 & -0.09 & -0.02 \\
\hline Jensen's alpha & $-2.3 \%$ & $-1.0 \%$ & $-0.8 \%$ & $-1.1 \%$ & $-2.6 \%$ & $0.0 \%$ \\
\hline
\end{tabular}

Notes: All returns are calculated in Swiss Franc.

$* * *, * *$ and $*$ indicate significance at $1 \%, 5 \%$ and $10 \%$ level, respectively.

Wine appears to behave differently depending on wine type. All wine indices exhibit a skewness closer to zero and a lower excess kurtosis than stocks, which suggests that returns more closely follow a normal distribution. While returns are rather disappointing, different measures indicate lower risk. It also becomes apparent that wine is useful for portfolio diversification. All wine indices display a medium correlation (0.4-0.6) with financial assets. Although these correlations slightly increase for the crisis period they remain quite constant across time. As described in Sanning et al. (2008) and Masset and Weisskopf (2010) wine also exhibits a low beta coefficient. All in all, it does not appear that wine was a good investment when looking at returns. However, all other attributes, related to risk and diversification, suggest it was a good addition to an investor's portfolio. We thus only find limited support for Hypothesis 2 as all fine wines strongly underperformed bonds and only the most prestigious fared better than stocks. 
These results contrast with recent evidence on the fine wine market. In particular, the returns to an investment in fine wine appear low as compared to Sanning et al. (2008) and Masset and Weisskopf (2010) who use a similar sample period. The difference in our findings can be explained by the monetary environment Switzerland faced over this period. The wine market being globalised, prices all over the world follow similar patterns. Thus, the strong appreciation of the Swiss franc versus the Euro (and other currencies) over the sample period has led to a downward adjustment in wine prices expressed in CHF. In order to take this effect into account and to reconcile our results with prior literature, we redo all our calculations using prices in Euro.

In Table 2, we thus perform the same calculations, but for indices translated into Euro and for a pan-European stock and bond index. Indeed, results suggest that wine becomes a better investment when expressed in Euro. In this case, all wine indices outperform stocks. This is not only true for returns, but also for risk-adjusted measures such as the Sharpe and Treynor ratio due to a very low volatility and beta coefficient.

Table 2 Performance indicators of wine and European assets

\begin{tabular}{|c|c|c|c|c|c|c|c|}
\hline \multicolumn{8}{|c|}{ Panel A: Performance of wine and European assets (2002-2012) } \\
\hline & All & $\begin{array}{c}\text { lst } \\
\text { growth } \\
\text { Médoc }\end{array}$ & $\begin{array}{c}\text { 1st } \\
\text { growth } \\
\text { Libourne }\end{array}$ & $\begin{array}{l}\text { Super } \\
\text { second }\end{array}$ & $\begin{array}{c}\text { Other IG } \\
\text { wines }\end{array}$ & DJSTOXX50 & $I B O X X$ \\
\hline Average & $0.8 \%$ & $5.0 \%$ & $3.0 \%$ & $1.6 \%$ & $0.7 \%$ & $2.9 \%$ & $4.3 \%$ \\
\hline Volatility & $10.2 \%$ & $15.4 \%$ & $15.3 \%$ & $14.5 \%$ & $13.2 \%$ & $20.7 \%$ & $5.1 \%$ \\
\hline Skewness & -0.64 & 0.04 & -1.17 & 0.07 & -0.30 & -1.97 & 0.56 \\
\hline Kurtosis & 4.16 & 2.85 & 5.73 & 2.19 & 2.87 & 8.20 & 5.35 \\
\hline Correlation & 0.57 & 0.43 & 0.49 & 0.42 & 0.46 & 1.00 & -0.18 \\
\hline Max. drawdown & $-25.0 \%$ & $-30.3 \%$ & $32.6 \%$ & $-28.6 \%$ & $24.1 \%$ & $-54.9 \%$ & $-5.9 \%$ \\
\hline Beta & $0.28 * * *$ & $0.32 * * *$ & $0.36^{* * *}$ & $0.30 * * *$ & $0.30 * * *$ & 1.00 & -0.04 \\
\hline Sharpe ratio & -0.14 & 0.18 & 0.05 & -0.04 & -0.12 & -0.24 & 0.41 \\
\hline Treynor ratio & -0.05 & 0.09 & 0.02 & -0.02 & -0.05 & -0.05 & -0.55 \\
\hline Jensen's alpha & $0.0 \%$ & $4.4 \%$ & $2.6 \%$ & $0.9 \%$ & $0.0 \%$ & $0.0 \%$ & $1.9 \%$ \\
\hline \multicolumn{8}{|c|}{ Panel B: performance of wine and stocks in Switzerland (2008-2012) } \\
\hline & All & $\begin{array}{c}\text { lst } \\
\text { growth } \\
\text { Médoc }\end{array}$ & $\begin{array}{c}\text { 1st } \\
\text { growth } \\
\text { Libourne }\end{array}$ & $\begin{array}{l}\text { Super } \\
\text { second }\end{array}$ & $\begin{array}{c}\text { Other IG } \\
\text { wines }\end{array}$ & DJSTOXX50 & $I B O X X$ \\
\hline Average & $3.9 \%$ & $5.0 \%$ & $5.5 \%$ & $5.2 \%$ & $3.6 \%$ & $-2.7 \%$ & $5.5 \%$ \\
\hline Volatility & $11.4 \%$ & $20.6 \%$ & $16.2 \%$ & $14.6 \%$ & $14.0 \%$ & $26.1 \%$ & $6.5 \%$ \\
\hline Skewness & -0.60 & 0.18 & -0.39 & 0.32 & 0.00 & -1.65 & 0.23 \\
\hline Kurtosis & 2.63 & 2.07 & 2.16 & 1.82 & 2.49 & 6.31 & 4.61 \\
\hline Correlation & 0.60 & 0.45 & 0.44 & 0.36 & 0.53 & 1.00 & -0.02 \\
\hline Max. drawdown & $-12.0 \%$ & $-30.3 \%$ & $-14.0 \%$ & $-14.6 \%$ & $-12.7 \%$ & $-38.1 \%$ & $-5.9 \%$ \\
\hline Beta & $0.27 * * *$ & $0.36^{* *}$ & $0.27 * *$ & 0.20 & $0.29 * * *$ & 1.00 & 0.00 \\
\hline Sharpe ratio & 0.27 & 0.20 & 0.28 & 0.30 & 0.19 & -0.14 & 0.71 \\
\hline Treynor ratio & 0.11 & 0.12 & 0.17 & 0.21 & 0.09 & -0.04 & 424.53 \\
\hline Jensen's alpha & $4.0 \%$ & $5.4 \%$ & $5.6 \%$ & $5.1 \%$ & $3.7 \%$ & $0.0 \%$ & $4.7 \%$ \\
\hline
\end{tabular}

Notes: All returns are calculated in Euro.

$* * *, * *$ and $*$ indicate significance at $1 \%, 5 \%$ and $10 \%$ level, respectively. 
Comparing wine to bonds yields different result. Bonds are the most interesting asset to hold during the complete period and even more so during the financial and economic crisis. Returns are higher and volatility lower than for wine and stocks. This positively impacts measures such as the Sharpe and Treynor ratio. Moreover, bonds also seem to be a better instrument to diversify a portfolio as it exhibits a low correlation to other assets and a low, but insignificant beta. These results confirm the high risk-aversion of investors as quality bonds are highly demanded.

As apparent in Figure 4 there is evidence that Lafite has experienced a particular evolution. This visual evidence is confirmed by results in Table 3 in which we analyse an index of the first growth from Médoc (without Lafite Rothschild) and a Lafite index.

Table 3 Performance of Médoc wines, Lafite and European assets

\begin{tabular}{|c|c|c|c|c|}
\hline \multicolumn{5}{|c|}{ Panel A: performance of wine and European assets (2002-2012) } \\
\hline & $\begin{array}{l}\text { 1st growth Médoc } \\
\text { w/out Lafite }\end{array}$ & Lafite & DJSTOXX50 & $I B O X X$ \\
\hline Average & $4.2 \%$ & $9.9 \%$ & $-2.9 \%$ & $4.3 \%$ \\
\hline Volatility & $15.1 \%$ & $23.9 \%$ & $20.7 \%$ & $5.1 \%$ \\
\hline Skewness & 0.08 & -0.09 & -1.97 & 0.56 \\
\hline Kurtosis & 2.56 & 2.59 & 8.20 & 5.35 \\
\hline Correlation & 0.42 & 0.35 & 1.00 & -0.18 \\
\hline Max. drawdown & $-25.2 \%$ & $-50.3 \%$ & $-54.9 \%$ & $-5.9 \%$ \\
\hline Beta & $0.31 * * *$ & $0.40 * * *$ & 1.00 & -0.04 \\
\hline Sharpe ratio & 0.13 & 0.32 & -0.24 & 0.41 \\
\hline Treynor ratio & 0.07 & 0.19 & -0.05 & -0.55 \\
\hline Jensen's alpha & $3.6 \%$ & 9.8 & $0.0 \%$ & $1.9 \%$ \\
\hline \multicolumn{5}{|c|}{ Panel B: performance of wine and European assets (2008-2012) } \\
\hline & $\begin{array}{l}\text { 1st growth Médoc } \\
\text { w/out Lafite }\end{array}$ & Lafite & DJSTOXX50 & $I B O X X$ \\
\hline Average & $4.6 \%$ & $9.4 \%$ & $-2.7 \%$ & $5.5 \%$ \\
\hline Volatility & $19.4 \%$ & $30.8 \%$ & $26.1 \%$ & $6.5 \%$ \\
\hline Skewness & 0.20 & -0.12 & -1.65 & 0.23 \\
\hline Kurtosis & 1.97 & 2.05 & 6.31 & 4.61 \\
\hline Correlation & 0.44 & 0.32 & 1.00 & -0.02 \\
\hline Max. drawdown & $-25.2 \%$ & $-50.3 \%$ & $-38.1 \%$ & $-5.9 \%$ \\
\hline Beta & $0.33 * *$ & 0.39 & 1.00 & 0.00 \\
\hline Sharpe ratio & 0.19 & 0.28 & -0.14 & 0.71 \\
\hline Treynor ratio & 0.11 & 0.22 & -0.04 & 424.53 \\
\hline Jensen's alpha & $4.9 \%$ & $9.9 \%$ & $0.0 \%$ & $4.7 \%$ \\
\hline
\end{tabular}

Notes: All returns are calculated in Euro.

$* * *, * *$ and $*$ indicate significance at $1 \%, 5 \%$ and $10 \%$ level, respectively.

As shown in Table 3 Lafite strongly outperforms all wine indices and stock markets in terms of returns and risk-adjusted returns. It displays returns of around $10 \%$ p.a. over the total period as well as during the crisis. This high return is, however, accompanied by 
higher risks of up to $30 \%$. Moreover, Lafite wines also have a maximal drawdown of $50 \%$ during the period 2011-2012. However, this large outperformance once again is not better than an investment in bonds. The very low volatility of bonds paired with an unnaturally high return leads to high risk-adjusted returns. These results lend support to hypothesis 2 as fine wine has effectively delivered a strong performance in Switzerland but a substantial part of the returns has been lost for investors due to the rapid increase in the Swiss Franc. Our findings are thus reconciled with other recent evidence on the wine market and extend results by Masset and Weisskopf (2010) who find that economic factors have an impact on the evolution of wine prices.

\section{Conclusions}

This paper studies the price evolution and the performance of an investment in fine wine on the Swiss market over the period 2002-2012. Using a repeat-sales-regression approach we calculate different wine indices based on auction hammer prices obtained by Steinfels Weinauktionen. Evidence indicates that the Swiss wine market only partially follows the positive attributes related to wine found on other markets.

The different wine indices appear to evolve in similar patterns through time but the amplitude of returns varies considerably. Wines from Burgundy, second wines of Bordeaux and Lafite Rothschild show the strongest performance while Bordeaux in general, the Rhône valley and Italy show a poorer performance. Overall, wine appears to have outperformed or at least performed equally well as stocks over the sample period. Concerning risk the most liquid wines (first growth from Médoc) display the highest volatilities which become similar to stock volatilities. Potential diversification benefits appear to be the most interesting venue for investors with correlations of $0.4-0.6$ of wine with stocks and a low beta.

These somewhat positive characteristics of wine as compared to stocks are, however, lost when looking at bonds. The European bond market has been the best investment over the analysed period in every respect. Its high returns coupled with low volatilities, correlations and beta make it the ideal addition to investor portfolios. Further considering the ease with which investors can invest in bonds or bond ETF an investment in wine becomes even less attractive.

We further find that the strong appreciation of the CHF/EUR exchange rate over the period 2008-2012 has had an influence on wine performance. Returns as well as all performance measures have increased. Correlations and beta have slightly decreased for a volatility that remains unchanged.

\section{References}

Bentzen, J.B., Smith, V. and Leth-Sørensen, S. (2002) Prices of French Icon Wines and the Business Cycle: Empirical Evidence from Danish Wine Auctions, Working paper, Centre for International Economic Studies, Adelaide University.

Burton, B.J. and Jacobsen, J.P. (2001) 'The rate of return on investment in wine', Economic Inquiry, Vol. 39, No. 3, pp.337-350.

Byron, R.P. and Ashenfelter, O. (1995) 'Predicting the quality of an unborn grange', Economic Record, Vol. 71, No. 212, pp.40-53. 
Di Vittorio, A. and Ginsburgh, V. (1996) 'Des enchères comme révélateurs du classement des vins. Les grands crus du Haut-Médoc', Journal de la Société Statistique de Paris, Vol. 137, No. 2, pp.19-49.

Fogarty, J.J. (2006) 'The return to Australian fine wine', European Review of Agricultural Economics, Vol. 33, No. 4, pp.542-561.

Fogarty, J.J. (2007) Rethinking Wine Investment in the UK and Australia, AAWE Working paper, American Association of Wine Economists.

Fogarty, J.J. (2010) 'Wine investment and portfolio diversification gains', Journal of Wine Economics, Vol. 5, No. 1, pp.119-131.

Fogarty, J.J. and Sadler, R. (2014) 'To save or savor: a review of approaches for measuring wine as an investment', Journal of Wine Economics, Vol. 9, No. 3, pp.225-248.

Jaeger, E. (1981) 'To save or savor - the rate of return to storing wine', Journal of Political Economy, Vol. 89, No. 3, pp.584-592.

Kourtis, A., Markellos, R.N. and Psychoyios, D. (2012) 'Wine price risk management: international diversification and derivative instruments', International Review of Financial Analysis, Vol. 22, pp.30-37.

Krasker, W.S. (1979) 'Rate of return to storing wines', Journal of Political Economy, Vol. 87, No. 6, pp.1363-1367.

Markowitz, H. (1952) 'Portfolio selection', Journal of Finance, Vol. 7, No. 1, pp.77-91.

Masset, P. and Henderson, C. (2010) 'Wine as an alternative asset class', Journal of Wine Economics, Vol. 5, No. 1, pp.87-118.

Masset, P. and Weisskopf, J.P. (2010) Raise Your Glass: Wine Investment and the Financial Crisis, AAWE Working paper, American Association of Wine Economists.

Masset, P. and Weisskopf, J.P. (2015) 'Wine funds: an alternative turning sour?', Journal of Alternative Investments, Vol. 17, No. 4, pp.6-20.

Masset, P., Weisskopf, J.P., Faye, B. and Le Fur, E. (2015) Red Obsession: The Ascent of Fine Wine in China, Working paper.

Meltzer, P.D. (2012) 'Global wine auctions reach new high in 2011' [online] http://www.winespectator.com/webfeature/show/id/46258 (accessed 24 August 2012).

Rose, A. (2011) 'Wine investment - my take at the Hong Kong international wine \& spirits fair' [online] http://www.anthonyrosewine.com/journal/2011/11/ wine-investment-my-take-hongkong- international-wine-spirits-fair (accessed 15 April 2012).

Sanning, L., Shaffer, S. and Sharratt, J.M. (2008) 'Bordeaux wine as a financial investment', Journal of Wine Economics, Vol. 3, No. 1, pp.51-71.

Swiss National Bank (2013) Switzerland's International Investment Position 2012, Swiss National Bank, Zurich.

Weil, R. (1993) 'Do not invest in wine, at least in the US unless you plan to drink it, and maybe not even then', 2nd International Conference of the Vineyard Data Quantification Society, Verona.

\section{Notes}

1 CIVB stands for Conseil Interprofessionnel du Vin de Bordeaux and BIVB for Bureau Interprofessionnel des Vins de Bourgogne. Both represent producers of their respective regions.

2 As of November 2014, Arvi had around 190 cases of Lafite Rothschild 2006 and Mouton Rothschild 2010 for sale - this roughly corresponds to $1 \%-2 \%$ of the total production of these much sought-after wines. 
3 It is considered as one of the three large European markets for wine auctions with London and Paris. For example, according to Christie's 21\% of their 2012 turnover at wine auctions emanated from Geneva auctions with 9\% from Amsterdam, 16\% form Paris and 54\% from London.

4 While only including one auction house may be considered a limitation to this study we argue that Steinfels best represents the Swiss market and its customers as Christie's customers tend to be more international. Contrary to other auction houses active in Switzerland, Steinfels organises an auction every quarter and not on an irregular basis once a year. It further allows us to be comparable to other studies which use only one auction house to infer the evolution of wine prices [e.g., Masset and Henderson (2010) and Sanning et al. (2008) use The Chicago Wine Company for the US market or Fogarty (2006) uses Langton's for Australia]. Moreover, the use of several auction houses may introduce some heterogeneity in data and time interval between auctions which may lead to biased price estimates.

5 The complete list is available upon request.

6 The indices that we analyse and report hereafter have been estimated using OLS. As a robustness check, and in order to account for the fact that the residuals often display a positive excess kurtosis, we have also estimated the indices using WLS (following Case-Shiller's approach) and using winsorized returns (in order to avoid having indices affected by potential outliers). In all cases, overall results remain qualitatively similar.

7 Other approaches used to estimate wine indices include the hedonic pricing model or hybrid model. The interested reader can find an application and comparison of all three techniques in Fogarty and Sadler (2014).

8 According to statistics of the Swiss National Bank (2013) some 58\% of foreign portfolio holdings in 2012 went into the 27 countries of the European Union. 